\title{
Reform Movements in Turkish Industrial Relations: Assessment of New Trade Unions and Collective Bargaining Law No:6356
}

\section{M.Caglar Ozdemir}

\author{
Ass.Prof. (PhD), University of Sakarya, \\ Department of Labor Economics and Industrial Relations, Turkey \\ cozdemir@sakarya.edu.tr \\ Ekrem Erdogan \\ Ass.Prof. (PhD), University of Sakarya, \\ Department of Labor Economics and Industrial Relations, Turkey, \\ eerdogan@sakarya.edu.tr
}

\author{
Doi:10.5901/ajis.2013.v2n9p714
}

\section{Abstract}

Turkey has made significant progress toward more democratic labor relations last decade. These reforms are in progress with the Law No. 6356 come into force on November 7, 2012 by the Law on Trade Unions and Collective Bargaining. This law was established by combining Trade Unions Law No.2821 and Collective Bargaining, Strike and Lockout Law No.2822 (Both dated 1983). Now there is just one law for trade unions and collective bargaining and the law aims at to have operations in more democratic environment of all parties. But of course it has some adequate and inadequate effects. This study aims to evaluate the effects of the new Trade Unions and Collective Bargaining Law No.6356 on Turkish Industrial Relations System. The study has mainly structured in three sections. In the first part, the reasons of changing made by law on trade unions and collective bargaining (6356) are discussed. In the second part, the arrangements introduced by new law has examined in detail. In this section the arrangements have also examined within the framework of positive and negative aspects. In the last section, the possible effects of the new regulations on Turkish Industrial Relations System are examined. Within the new Trade Union and Collective Bargaining Law, the new period has been started. Although we can estimate the some positive and negative aspects of the new law, time will show the truth to Turkish Industrial Relations. There are lots of discussions about the new regulation between all parties. Some of them acknowledge that Turkey is approaching to the EU standards day by day, the others believe that labour relations deteriorating day by day. Actually some of the international organisations such as ITUC and ETUC are also supporting the second view.

\section{Introduction}

Turkey has been in a key transition period in the field of working relations for the last decade just like in many other areas. The Law no 6356 on Trade Unions and Collective Bargaining which was enforced Ob $7^{\text {th }}$ of November, 2012 is also a part of this transition. The alteration of the Trade Unions Law (ITUC, CIS, IGB, 2012) has become applicable despite many reactions from social stakeholders. This study has been prepared with the goals of presenting current changes in working life, reflecting the reactions shown thereto and discussing the possible results.

The Methodology of Study

The study has been constructed on three titles. In the first section the needs for alteration on the Law of Trade Unions and Collective Bargaining has been discussed. In the second section the adjustments made via new law has been presented generally and pros and cons has been discussed. In the last part the possible effects of the new regulation on Turkish Industrial Relations has been discussed.

\section{Why a new law is needed?}

The industrial relations are dynamic as being a part of natural life. The issues of employer and employee are getting to different levels each passing day. The organized labor force structure which had arisen as a mass movement has lost its power in the last thirty years and has become fragmented (Aidtand Tzannotoz,2002). For the purposes of the needs of the dynamics labor market and for a more libertarian environment regulations have been enforced in the constitution with 
law no 5892, 2010 for more extensive rights and liberties for unions. This regulation has required alteration in Union Law no 5982, 2010 and Collective Bargaining Strike and Lock-Out Law no 2822 (ETUC, 2010). As per the end of 2012 this alteration has been concluded via new Trade Unions and Collective Bargaining Law no 6356. The law states that, "it is aimed to re-regulate the union rights and liberties and Collective Bargaining and free collective bargaining rights within the more libertarian and democratic society by taking reaction of Turkish working life to the universal norms all along the line" (general justification of law no 6356, www.tezkoopis.org/kaynak/6356.pdf). Within this context the need for a new law can be listed as;

1. Need for a lasting law to carry Turkish Industrial relations to forward, to reflect the values of the time and to bring substantial solutions to the problems of Turkish working life

2. To harmonize with standards of EU and particularly ILO conventions No.87 and No.98

3. To facilitate the operation principles for working relations within Turkey by collecting under a single law

4. To meet the needs the social stakeholders efficiently by considering all of the accumulated problems.

\section{Regulations on New Trade Unions and Collective Bargaining Law No:6356}

The law has been structured in two parts as Trade Unions and Collective Bargaining. It has been comprised of a total of 12 sections (6 for unions and 6 for collective bargaining), 83 articles and 6 provisional articles. Thus the texts of law no 2821 and 2822 have been integrated into a single law (Dereli, 2013).

\subsection{Trade Unions Law}

The first 6 sections and 32 articles of law no 6356 has been saved for Trade Unions. The general objective has been mentioned in the first article of the law and a reconciliatory structure has been evoked instead of a dissentious structure by mentioning regulations regarding amicable solutions of the conflicts.

\subsubsection{Definitions}

The definitions such as Responsible Authority, Group Collective Bargaining and Framework Contract are clearly expressed. Framework Contract is a new concept for Turkish Trade Unions Law. It represents the contract in the level of profession among the trade unions and employer's unions who are members of the trade unions and employer's unions represented in the Economical and Social Council. (Dereli,2013).

\subsubsection{Regulations on structure of Trade Unions, Establishment and its Founders}

The regulations regarding the establishment freedom of the trade unions have been removed of details and simplified. The number of professions has been decreased from 28 to 20. The provisions stipulating being a Turkish citizen and an active worker in the relevant profession to establish a trade union have been revoked. Besides the crimes against the constitutional order and operation thereof, against the national defence, against the state secrets and espionage have been revoked and only the general provisions stated in article 53 of Turkish Criminal Code such as bribery, theft and fraud have been mentioned.

There has been a change in the numbers of the management boards of the trade union branch and the confederation which accordingly branches of trade union management boards shall be comprised of at least three and at most five personnel (used to be nine) and whereas confederation management boards shall be comprised of at least five and at most twenty two personnel (used to be twenty nine).

The provision stipulating the requirement of at least five hundred workers for trade union general meeting and at least two hundred and fifty workers for general meeting of trade union branch has been revoked. This issue may be freely regulated in the charters of the trade unions (Basbug, 2102).

\subsubsection{Regulations on Trade Union Membership}

The new law reduced the eligible age of being a membership from sixteen to fifteen. Whilst the positive and negative trade union freedom are preserved, more than one trade union membership is provided to the workers working under different employers in same sector. 
Another striking regulation brought for membership is that the condition of notary public has been revoked and that membership application has been made available via e-state gateway. Unless the application is rejected by the trade union within 30 days the membership is deemed to accept.

Membership fees may be freely determined within the charters of the trade unions now. The membership scope of the trade unions for international institutions has also been extended (Kolcuoglu, 2013).

\subsubsection{Regulations on Trade Union Freedoms}

Engaging in union activities is among the basic rights and freedoms just like in the previous law (EU-Turkey Joint Consultative Committee, 2012). However one of significant regulations of this law is that the workers who are beneficiaries of Labor Act no 4857, shall have right to sue in case of termination of the labor contract due to union related causes (Baskan, 2013). Job security provisions shall be applicable for workers who have been working at least 30 days for workplace having at least 30 personnel working within.

\subsubsection{Regulations on Assurance of Trade Union Leader}

The new law contains provisions regarding assurance of the trade union managers and workplace representatives just like the previous law. The trade union managers may leave their jobs with severance pay and may return back to their job when their managerial duty is over.

The rights of the trade union representatives are extended in the new law. The amateur trade union representatives also have the same rights with the trade union representatives (Akyigit, 2012; Şahlanan, 2013). Thus the lack of assurance issue which was criticised in the previous law seems to be covered relatively (Özkaraca, 2013)

\subsubsection{Regulations on Trade Unions Activity}

In the new law where the trade unions are allowed to act freely the commerce and politics are still forbidden for them. The trade unions are short in the effort of their establishment reason of defending the rights and benefit of the members when they can't perform political acts. As the trade unions lost pace in other social activities due to the general structure no restrictions imposed legally thereof (Ersinadım, 2012).

\subsection{Collective Bargaining Law}

The last 6 section of law no 6356 (sections 7-12) and articles 33 to 75 have been spared for Collective Bargaining.

\subsubsection{Regulations on Structure of Collective Bargaining and its Species}

The most recent regulation enforced regarding the collective bargaining is Framework Contract. With the help of this contract it is aimed to establish common regulation frameworks (Aktay,.2012). Regulations regarding the labor health and safety, social responsibility and employment policies may be arranged via framework contracts (Alpagut, 2012).

\subsubsection{Regulations on Collective Bargaining Competence}

The threshold required for collective bargaining competence of $10 \%$ of the previous law has been reduced to $3 \%$. This rate shall be applied as $1 \%$ for the ESK member trade unions for the first three years (until 2016). The practice of 50\%+1 for the workers of the workplace where the contract shall be signed is still ongoing for determining of the competence. The competence is still determined by the state (Ministry) same as before (Onsal, 2012).

\subsubsection{Regulation on Collective Bargaining Utilization}

Like in the previous law the right of utilization of the collective bargaining stands with the members. The non-members may utilize from the provisions of the bargaining by paying solidarity fee. The solidarity fee is determined in the charters provided not to exceed the membership fee (Canbolat, 2012). 


\subsubsection{Regulation on Strike and Lockout}

In the provisions regarding the strike and lock-out, particularly in the group collective bargaining, the scope of application of lock out has been expanded. It is seen that all the workers are included into the strike voting and thus the utilization of strike right has been shrinked. The strike prohibition is ongoing in banking services (Caniklioglu, 2012).

\subsection{Evaluation of the Positive and Negative Aspects of New Trade Unions and Collective Bargaining Law Arrangements}

The new trade unions and collective bargaining law, has been enforced together with the reactions, expectations and loss of the social stakeholders. Although some issues particular to Turkey have been remedied there have also been some negative regulations which draw reactions. ETUC and ITUC have shown substantial reactions to the negative regulations to restrict the trade union rights and freedoms and moreover they could not achieve and positive result from the letter written by General Secretary of ITUC addressing to the Prime Minister (Sendika.org, 2013).

Despite being more compact as being a single law it is seen that the cons of the new law likely to be more than pros (Kutal, 2012; Celik, 2012)

\subsubsection{Positive Aspects}

First of all having integrating two laws under one frame is a positive regulation.

In the new law, the number of the professions, which are in discussions for many years have been reduced. The number of professions stated in the previous Trade Unions Law no 2821 which was 28 has been reduced to 20. Although this regulation will also be examined under the negative aspects below we believe it to be a proper decision from the point of organizing the loose professions.

Another significant issue is that the age of membership to trade union has been reduced to 15 . It can be said that this regulation will have a positive effect on both protecting the right of the young workers and youth to become accustomed to nongovernmental organizations.

The notary public condition which was previously required to be a member of the trade unions has been revoked. Now it is possible to become a member to the trade unions and to quit the membership via e-state. Although this implementation is evaluated as negative from time to time (for the aspects such as the trade union members may change in very short time and the control of the state) it is a positive regulation by the aspects of harmonization to the current conditions and easiness of organization. However only time will show the possible deficiencies of the future (Kutal, 2012).

Another regulation is that it provides right of collaborating with other international institutions along with membership. It is meaningless to shackle the trade unions of our country in a time when globalization has been spread out everywhere. This regulation provided improvement in international efficiency of the trade unions and also their visions.

Extension of the assurance provided to the workplace representatives is an important regulation regarding the protection of right to association. Especially the extension towards the amateur trade union representatives is expected to improve the potential of unionization. This regulation is also in conformity with the contract no 135 of ILO (Kutal, 2012).

In audit of the trade unions the activation of the independent accountants provides both supports the previous regulations (removal of state audit) and a proper audit process in conformity with ILO norms.

\subsubsection{Negative Aspects}

It should also be determined the negative aspects of the provisions of the law. First of all the function and efficacy of the new concept of "framework contract" shall be discussed. According to the law the contract is defined as a profession based contract signed between the trade unions and employer's unions which are members of the trade unions and employer's unions represented in the economical and social level. Even if we think that this contract is conducted to create a competition environment (like labor health and safety standards) there is no significant regulation regarding its validity and sustainability. Shortly this contract is not a must one. Moreover there is no clear explanation on which sanction shall provide its binding when it is conducted (Kutal, 2012).

We encounter another important regulation under the title of definitions. It is said that "the terms of worker, employer and workplace are as defined in Law no 4857 as per the implementation of this law". However for many years it has been emphasized in academic and union communities that the terms of individual law and collective labor law cannot 
be compatible. For avoidance of confusion of the terms it should be better to define each terms in law no 6356 and also referring these definitions to another law is against the contract no 98 of ILO.

Another inappropriate regulation is that the professions are still being determined by the Ministry of Labor. However according to the ILO norms it should be better that this fixation to be made by a commission to be comprised of worker-employer and state triangle. Moreover fixation of the profession by regulation instead of charter creates a situation that the state can do work place replacement under the discretion of the government for the relevant professions and which makes us hard to understand the resetting this regulation which we changed many years ago (Celik, 2012).

According to the Law no 6356, more than 1 year of unemployment causes the termination of trade union membership. One must say that this regulation is inappropriate for a country like Turkey where long-term unemployment is not rare. Moreover this regulation is contrary the contract no 87 of ILO.

For many years the obligation of the trade union representatives to quit their duties within the trade union when they are elected in general or local elections. These people are elected with the commitment of protecting their rights and benefits. It is of no use for these people to be forced to cut relation with the mass that they represent. The direct representation authority of the political arena shall be re-defined and it shall be proper to make adjustments in EU standards particularly (Kutal, 2012).

Another inappropriate regulation is regarding the individual trade union rights. In the sub clause 5 of the article 25 of the Law titled Trade Union Freedom Assurance of the Law it is referred to the relevant provisions of the Labor Law for the breach of trade union rights and this raises doubts on how persons not entitling this right can protect its rights. This situation is clearly contrary to the contract no 87 of ILO.

It is also an important inappropriateness to remove the provision of sparing and expending $10 \%$ of their income for training activities. Moreover it would be much proper to continue with previous regulation in parallel of the recognition of the Training Profession with the new Law which is a positive aspect.

The situation regarding the Collective Bargaining is as follows:

The requested number of members for the competency along with the professions has been reduced in the law. The requested member rate for the entire country has been reduced from $10 \%$ to $3 \%$. However it can not be said that this rate decreased in real terms in parallel with this reduction. According to some calculations this rate is $24 \%$ in some professions (DISK, 2012). Of course this creates an important obstacle in organization. Moreover these kind of numerical regulations become subject to critics as they are contrary to contract no 87 and 98 of ILO (Demir, 2012-2013).

The group contracts have the risk of causing strikes and lockouts despite being more openly arranged than previous law (2822).

The regulations identifying the way to how the collective bargains shall be conducted in cases of consolidation and transfer of the trade unions is a positive development.

There has been some changes regarding the provisions of the voting of strike. In the previous law no 2822 the workers who are member of the trade union had voting right for strike, with the new law this is only given to the participants of the strike. We believe ILO, supporting all kinds of regulation to remove the obstacles for strike will not support these measures regarding removing strike decision more easily.

\section{Assessment of New Trade Unions and Collective Bargaining Law in terms of bring about changes on Turkish Industrial Relations System}

The new Trade Unions and Collective Bargaining Law has been prepared in order to bring proper regulations for the current conditions. The law with the main objective of harmonization to EU and ILO norms still seems to have substantial shortages (Friedrich Ebert Stiftung , 2012). Moreover it is a doubt in minds that how some regulations made in order to harmonize EU norms be actively utilized. The obstacles of trade union organization in Turkey can not only be looked for in legal ground. The constituent of trade union structure is democratically mature minds. Without achieving this it is a mistake to except highly positive reflections from these regulations. For instance the issues of reducing the number of professions or decreasing the competency rate to $3 \%$ are perceived to be gains or losses yet the reality is beyond that. Even the competency rate in Turkey is decreased to $0 \%$ the reaction of the current economical order against organizing of trade unions shall be considered deeply. Moreover this reaction is not only limited with Turkey. It is clear that in the entire world the trade union organizational structure is in decline. Therefore what has to be done is not to remove or rearrange the regulations which were seen to be obstacles in the past but to be in an effort to provide trade unions a new mission/re-define them. The trade unions will continue to be crunched under the current global economical wheel unless they are taken out of the traditional industrial relations. Re-structuring the trade unions in a level which is concerned by the entire society and to expand the area of effects shall be a realistic barrier against this decline. The alterations in 
legislation performed in Turkey are far from this perception and as long as they continue to be regulations bear the traces of the past the structure of trade of unions will not be in the desired level.

As Celik's declared; There are 1.4 million work places in Turkey which is subject to Labor Law. In $95 \%$ of these workplaces there are less than 30 workers are working. This means that 5.7 million of more than 11 million of workers which makes 52 percent of them are working in workplaces having less than 30 workers. These figures indicate that trade union organization provides no assurance in nearly all of the work place and for more than half of the workers (Celik, 2012a).

\section{Conclusion}

The new trade unions law has been enforced with its pros and cons. When it is considered generally the negative aspects are seem to be more. Making regulations under a single law, removing the notary condition in membership, reducing the required age for membership, the regulations which may help to the capacity of being member to the international institutions are positive aspects. On the other hand, harming the trade union assurance, reducing the profession and extending the organization universe, the still dominant role of the state, trade union-politics relation continuing to be stern and regulations to obstruct strike implementations indicates the negative aspects.

It needs to be expressed that the trade union challenge is a matter of a deeper mind. Of course the legislation has its part in trade union challenge. However even a near perfect legislation infrastructure cannot succeed without an organization culture and people who does not have the necessary faith for this challenge.

A new industrial relations era has commenced in Turkey regarding the new trade unions and collective bargaining law. Whatever regulations are made, it is clear that the trade unions and higher institutions will continue to lose power. Focusing only in legal regulations in creating a trade union culture and neglecting the organization culture within will help for nothing only for but more decline and loss of power.

\section{References $^{1}$}

Aktay,N., Arici,K., Senyen Kaplan,E.T. (2012), Labor Law, Gazi Pub., Ankara.

Aidt,T and Tzannotoz,Z. (2002), "Unions and Collective Bargaining: Economic Effects in a Global Environment", The World Bank Directions of Development, Washington D.C.

Alpagut, G.(2013), "The Innovations of Trade Union and Collective Bargaining Law No.6356", Summit of New Laws in Working Life and Resolutions of Supreme Court, Istanbul, Corlu.

Canbolat, T. (2012), "The Innovations of the Trade Unions and Collective Bargaining Law", Toprak İşveren D. Aralık, Sayı: 96.

Caniklioglu, N. (2012), "New Regulations on solution of Collective Conflict of Trade Unions and Collective Bargaining Law No.6356" , Turkish Employer Unions Confederation, (tisk.org.tr/upload_duyuru_ekler/nursen_caniklioglu_sunum.pptx) (Turkish VersionAccess 6th June 2013).

Celik, A. (2012), "What the New Trade Unions Law brings and takes away?" Independent Internet Newspaper, (http://t24.com.tr/yazi /yeni-sendikalar-yasasi-ne-getiriyor-ne-goturuyor/5858) (Turkish Version -Access 8th June 2013).

Celik, A. (2012a), "Diagnose Them", Sendika Org , (http://www.sendika.org/2012/10/tani-bunlari-aziz-celik-birgun/) (Turkish Version Access 8th June 2013).

Celik, F.(2012b), "Law No. 6356 Aims to Bring Fundamental Solution to the Problems of Turkish Working Life", Toprak İşveren D. Aralık, Sayl: 96 (The author is currently Minister of Turkish Labor and Social Security).

Demir, F. (2012-2013), "Evaluation Series of New Trade Unions and Collective Bargaining Law", Gozlem Newspaper Article Series, (http://www.gozlemgazetesi.com/yazarlar/prof-dr-fevzi-demir/1654-toplu-is-iliskileri-5-sendika-uyeligi-ve-uyeligin-kazanilmasimd17.html) (Turkish Version -Access 3rd April2013).

Dereli, T.(2013), "New Trade Unions and Collective Bargaining Law No.6356: A General Evaluation" (Turkish Version- Calısma ve Toplum 2013/1.

ETUC (2010), "Turkish Trade Unions and Industrial Relations", April.

EU-Turkey Joint Consultative Committee (2012), "Trade Union Right Situation in Turkey", 30th meeting of the EU-Turkey Joint Consultative Committee (JCC), Berlin, Germany, 26-27 June (Reporters: Annie var Wezel, Prof.Dr. Ruchan ISIK).

Friedrich Ebert Stiftung (2012), Country Trade Union Report: Turkey, April.

ITUC, CSI, IGB (2012), Annual Survey of Violations of Trade Unions Rights (http://survey.ituc-csi.org/Turkey.html?lang=en\#tabs-1) (Access 2nd May 2013).

\footnotetext{
${ }^{1}$ (Most of the Turkish references' original title have been translated into English for the sake of clarity)
} 
Kolcuoglu, D.(2013), "Impact of New Law of Trade Unions and Collective Bargaining Agreements", Turkish Law Bulletin, November (http://www.kolcuoglu.av.tr/e-bulletin/Unions\%20and\%20Collective\%20Bargaining\%20Agreement\%20Law.pdf) (Turkish Version Access 7th May 2013).

Kutal, M(2005), "The adverse Conditions surrounding of Turkish Trade Unionism, Characteristics and need for a new structure", (Turkish Version), Calısma ve Toplum 2005/2.

Kutal, M. (2013), "Discussion on New Trade Unions and Collective Bargaining Law", Social Policy Conferences, Istanbul.

Onsal, N.(2012), "Barrage regulation on Trade Unions and Collective Bargaining Law", Toprak İşveren D. December, S. 96.

Trade Unions and Collective Bargaining Law,No:6356, Official Gazette Acceptance date: 07/11/2012 No: 28460.

Ozkaraca, E. (2012), "Trade Union Assurances in 6356 Law", (Turkish Version), Calısma ve Toplum 2012/1.

Akyigit, E.(2012), "Trade Unions' Executive Assurance in New Law", Legal IHSGHD, S.36.

Baskan, Ş.E. (2013), The termination of Employment Contract Caused by Trade Union in the Framework of 6356 Law, Ankara.

Alpagut, G. (2012), "Evualation of the Judgement of Collective Bargaining and Collective Bargaining Dispute in 6356 Law - Compliance with International Norms", Legal IHSGHD, S.35.

Başbuğ, A. (2012), Collective Labor Relations and Law, Trade Unions Law, Collective Bargaining Law, Discipline Law, Ankara.

Özveri, M. (2012), Trade Unions Rights, Trade Unions and Collective Barganing Law no: 6356, İstanbul.

Şahlanan, F. (2013), "Trade Union Workplace Representative Assurance", Sicil D., Y. 8, S. 29.

Ersinadım, H.(2012), "Legel framework of Social Activities of trade unions since 1961 Constitutition”, Kamu-l̇ş, C.12, S.4.

ITUC Genel Sekreteri Sharan Burrow'dan Başbakan'a mektup 17 Mart "The letter from ITUC General Secretary Sharan Brow to Prime Minister", (2013), Sendika.org, http://www.sendika.org/2013/03/ituc-genel-sekreteri-sharan-burrowdan-basbakana-mektup/ (Turkish Version- Access 5th July 2013). 